\title{
Correction: Defining the information needs of lung cancer screening participants: $a$ qualitative study
}

Ruparel M, Quaife S, Baldwin D, et al. Defining the information needs of lung cancer screening participants: a qualitative study. BMJ Open Respir Res 2019;6:e000448. doi: 10.1136/bmjresp-2019-000448.

The license type of the paper has changed from CC BY-NC to CC BY.

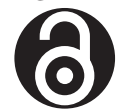

\section{OPEN ACCESS}

Open access This is an open access article distributed in accordance with the Creative Commons Attribution 4.0 Unported (CC BY 4.0) license, which permits others to copy, redistribute, remix, transform and build upon this work for any purpose, provided the original work is properly cited, a link to the licence is given, and indication of whether changes were made. See: https://creativecommons.org/licenses/by/4.0/.

(C) Author(s) (or their employer(s)) 2019. Re-use permitted under CC BY. Published by BMJ.

BMJ Open Resp Res 2019;6:e000448corr1. doi:10.1136/bmjresp-2019-000448corr1

A) Check for updates 